\title{
ARTICLE
}

\section{Diatom species diversity in the diet of healthy and sick specimens of adult Haliotis fulgens and Haliotis corrugata}

Diversidad de especies de diatomeas en la dieta de especímenes sanos y enfermos de adultos de Haliotis fulgens y Haliotis corrugata

\section{David Siqueiros-Beltrones ${ }^{1}$, Uri Argumedo-Hernández ${ }^{2}$, Nurenskaya Vélez-Arellano ${ }^{3}$ and Federico Andrés García-Domínguez ${ }^{3}$}

\begin{abstract}
'Departamento de Plancton y Ecología Marina, Instituto Politécnico Nacional, Centro Interdisciplinario de Ciencias Marinas, Av. Instituto Politécnico Nacional S/N, Col. Playa Palo de Santa Rita, La Paz, BCS, México. dsiquei@ipn.mx ${ }^{2}$ Departamento de Economía, Universidad Autónoma de Baja California Sur, km 5.5 Carretera al sur, La Paz, BCS, México ${ }^{3}$ Departamento de Pesquerías y Biología Marina, Instituto Politécnico Nacional, Centro Interdisciplinario de Ciencias Marinas, Av. Instituto Politécnico Nacional S/N, Col. Playa Palo de Santa Rita, La Paz, BCS, México
\end{abstract}

\begin{abstract}
Resumen.- Se analizó la diversidad de especies de diatomeas en la dieta de abulones azul (Haliotis fulgens) y amarillo (H. corrugata) del NW de México. Esta se referenció con valores de índices de condición y hepatogonádico (considerados como indicadores de la salud y cambios reproductivos, respectivamente) en ambas especies de abulón, incluyendo especímenes enfermos con síndrome de deshidratación (WS). Las hipótesis enunciaban que: a) las asociaciones representadas en contenidos intestinales de $\mathrm{H}$. fulgens vs. $\mathrm{H}$. corrugata mostrarían una estructura típica con muchos taxa raros y pocas especies abundantes; b) que no habría diferencia en la estructura de dichas asociaciones de diatomeas; y c) que las asociaciones de diatomeas en abulones con síndrome de deshidratación serían similares a las de especímenes sanos. Para contrastar las hipótesis se examinaron abulones sanos, recolectados entre febrero 2012 y febrero 2013, y especímenes enfermos recolectados entre marzo y mayo 2012. Los especímenes se pesaron y se midieron para calcular los índices de condición y hepatogonádico. Para analizar la diversidad de especies de diatomeas en contenidos intestinales de abulones se disecaron especímenes de 7 fechas de muestreo entre marzo y septiembre 2012. Las muestras de diatomeas se describieron con base en la abundancia relativa de las especies, índices de diversidad y de similitud. Para este período, 19 taxa de diatomeas comprendieron el $80 \%$ de las abundancias relativas; los más abundantes fueron Cocconeis scutellum, Gomphonemopsis pseudexigua, Grammatophora gibberula, Bacillaria socialis y Striatella unipunctata. La diversidad de especies de diatomeas fue alta en todas las muestras. Estos valores y la similitud medida entre muestras indican que ambas especies de abulón se alimentaron de las mismas asociaciones de diatomeas disponibles in situ a lo largo de este período. Las muestras de diatomeas de especímenes enfermos representaron asociaciones similares a las de especímenes sanos. Por lo tanto, no hubo evidencias para rechazar ninguna de las hipótesis planteadas.
\end{abstract}

Palabras clave: Diatomeas epifitas, diversidad de especies, abulones, Península de Baja California

\begin{abstract}
Diatom species diversity in the natural diet of healthy adult green abalone (Haliotis fulgens) and pink abalone (H. corrugata) from NW Mexico was analyzed and, referenced with values of condition index and hepato-gonadic index, used respectively as indicators of the health and reproductive season for the abalone. Likewise observations were done in abalone specimens affected with withering syndrome (WS). Our hypotheses stated that: a) the diatom assemblages represented in the gut contents of $\mathrm{H}$. fulgens vs. $\mathrm{H}$. corrugata would show a typical structure with few abundant taxa and many rare or uncommon species; b) no difference would be found between the structure of diatom assemblages in the gut contents of $\mathrm{H}$. fulgens and $\mathrm{H}$. corrugata; and c) diatom assemblages in abalone specimens with WS would be similar to those of healthy specimens. To test our hypotheses we examined healthy abalones collected from February 2102 to February 2013, and specimens with WS collected from March to May 2012. All specimens were measured and weighted and their condition and hepato-gonadic indices calculated. To analyze the diatom species diversity in gut contents of the abalone, specimens from 7 sampling dates from March to September 2012, were dissected. The diatom samples were described using species relative abundances, diversity indices and similarity between samples. For this period 19 diatom taxa comprised $80 \%$ of the relative abundances; the most abundant were Cocconeis scutellum, Gomphonemopsis pseudexigua, Grammatophora gibberula, Bacillaria socialis and Striatella unipunctata. High diversity values were estimated for diatom samples in all abalone specimens. Similarity and diversity values indicate that throughout this period both abalone species fed on the same diatom assemblages available in situ. Likewise, diatom samples in the guts of specimens affected by WS represented diatom assemblages similar to those of healthy specimens. No evidence was thus at hand for rejecting our hypotheses.
\end{abstract}

Key words: Epiphytic diatoms, species diversity, abalone, Baja California Peninsula 


\section{INTRODUCTION}

The lucrative abalone (Haliotis spp.) fishing industry from the middle of the XXth century in the Mexican north western region collapsed more than 40 years ago (SalasGarza \& Searcy-Bernal 1992) due to overexploitation, including pouching, but also to unforeseen changes in climate regime at that time. This most likely overran an unaware management that experienced sadly the lack of information on the complex ecology of said species. The above prompted concerned scientists to undertake autoecological studies mainly on restoration of abalone populations mainly through projects in aquaculture.

Adding to the management problem of this resource, the disease known as withering syndrome (WS) that affected the Haliotis spp. populations in the 1980's enhanced the difficulty in recovering the abalone industry. According to a review by García-Esquivel et al. (2011) to support a study on green abalone, specimens with withering disease show the following clinical signs: weakness, lethargy, shrinking of foot muscle, mantle retraction, poor gonad development, inability to tightly adhere to the substrate, and death. All this suggested a strong pathogen disease association. Said pathogen infects the epithelial cells lining the gut and enzymesecreting cells of the digestive diverticula causing the inability to eat in severely ill organisms.

Scientific research on the feeding habits of Haliotis spp. in the western coast of the Baja California peninsula (Mexico) began formally at the end of the 1990's with efforts directed toward determining their in situ diet. Some studies described the diet of young abalone (ServiereZaragoza et al. 1998, Guzmán del Próo et al. 2003), while others focused on adults (Mazariegos-Villarreal et al. 2012). All of which basically provided inventories of the macroalgae species found in their digestive tracts.

Concerning the diatom component in the diet of abalone, even after 2000, most studies consisted mainly of in vitro observations on early abalone juveniles or their post-larvae. Soon after, the first comprehensive inventories of diatoms available for abalone feeding in the wild became published (Siqueiros-Beltrones et al. 2004). Actual observations of the in situ feeding of young abalone on diatoms provided detailed species identifications (Siqueiros-Beltrones et al. 2004, 2005), while the lookout for selectivity in their feeding on certain diatom taxa increased the list of taxa included in their diet whilst discriminating the most important (ArgumedoHernández \& Siqueiros-Beltrones 2010).
Concerning adult abalone, it has been strongly accepted for decades that their diet is based solely on macroalgae, particularlly on Macrocystis pyrifera for this region. However, the potential importance of diatoms in the diet of adult abalone has been recently proposed (Siqueiros-Beltrones 2002, Siqueiros-Beltrones et al. 2004), supported by the fact that the macroalgae that they feed on, including $M$. pyrifera, represent a substratum that is densely covered by epiphytic diatoms. Allegedly, these would provide important nutritional elements to the adult abalone, either complementary or essential.

Notwithstanding the need for carrying out chemical analyses of said nutritional elements, it is first necessary to determine the association structure of those epiphytic diatoms that are actually forming part of the in situ diet of adult abalone (Haliotis spp.). This requires first to make a precise taxonomic inventory as the one supporting this study (Siqueiros-Beltrones \& Argumedo-Hernández 2015). The objective was to determine the species relative abundances and the species diversity of the diatoms identified in the gut contents of adult specimens of Haliotis fulgens (Philippi, 1845) and Haliotis corrugata (Wood, 1828) in their natural habitat. Previous results support our assumption that the diatom species found in the gut contents of both abalone species accurately represent their diverse availability in situ (SiqueirosBeltrones \& Argumedo-Hernández 2015).

The observations on the diatom based diet of healthy specimens of these abalone species and their time variations were referenced with measurements depicting their physical condition throughout a year, as well as with the characteristics related to their reproductive changes as seen in the hepato-gonadic index. Our hypothesis $\left(\mathrm{H}_{0}\right)$ stated that no difference would be found in the structure of diatom assemblages represented in the gut contents of $H$. fulgens as compared to $H$. corrugata, inasmuch they have similar feeding habits in a shared habitat. However, because a change in feeding habits may occur during the onset of the WS, similar observations were carried out in sick specimens, both for their gut contents as well as for their physical and reproductive condition, in order to record any anomaly in their diet that may be related to this disease. In this case our null hypothesis read that the diatom assemblages in the gut contents of specimens affected with WS would be similar to those described for healthy specimens. 


\section{Materials AND METHODS}

\section{HePATO-gONADIC AND CONDITION INDICES}

Monthly samplings from February 2012 to February 2013 were carried out in the vicinity of La Bocana $(26.0625 \mathrm{~N}$ and $112.287 \mathrm{~W})$, located on the NW coast of Baja California Sur (BCS), Mexico (Fig. 1). Around 30 specimens of Haliotis fulgens and 30 of $\mathrm{H}$. corrugata were collected on each date by scuba diving from a depth of 8 to $12 \mathrm{~m}$. Size and weight of the specimens varied between $90 \mathrm{~mm}$ and $190 \mathrm{~mm}$ and from 90 to $900 \mathrm{~g}$, respectively. Additionally, 20 specimens (18 $\mathrm{H}$. corrugata and $2 \mathrm{H}$. fulgens) showing symptoms of the WS were collected, 9 in March, 9 in April, 1 in May and 1 in July 2012 (Table 1). All specimens were kept for 2 or 3 days in abalone culture tanks at the Cooperativa Progreso de La Bocana, BCS and afterwards transported to the laboratories at CICIMAR-IPN in La Paz, BCS were they were measured and dissected.

With these, indicators of the abalone health condition and reproductive changes were used. The condition index provides a general view of the specimen's physical condition; taking the mean value as reference, higher values indicate that the organisms are in good health whilst low values indicate loss of weight, inasmuch it is calculated by dividing the fresh weight less the shell of the organism between its total weight, and expressed as a percentage. The hepato-gonadic index, used as an indicator of reproductive status (reproductive season) was estimated by dividing the weight of the hepatogonad complex by the weight of the specimen without shell and expressed as a percentage (Webber \& Giese 1968, Villalejo-Fuerte \& Ceballos-Vázquez 1996, Zetina et al. 2000).

\section{DiATOM SAMPLES}

For determining the diatom based diet of adult Haliotis fulgens and $H$. corrugata, out of the overall sampling period, 7 sampling dates: March, April, May, June, July, August and September 2012 were selected arbitrarily. From these, samples of gut contents were taken from only 118 specimens; 11 of these were affected by WS (Table 1). Guts were extracted, longitudinally opened with a scalpel and their contents retrieved using a $5 \mathrm{ml}$ plastic pippet. Gut contents were placed in a $250 \mathrm{ml}$ plastic bottle with $80 \%$ ethyl alcohol.
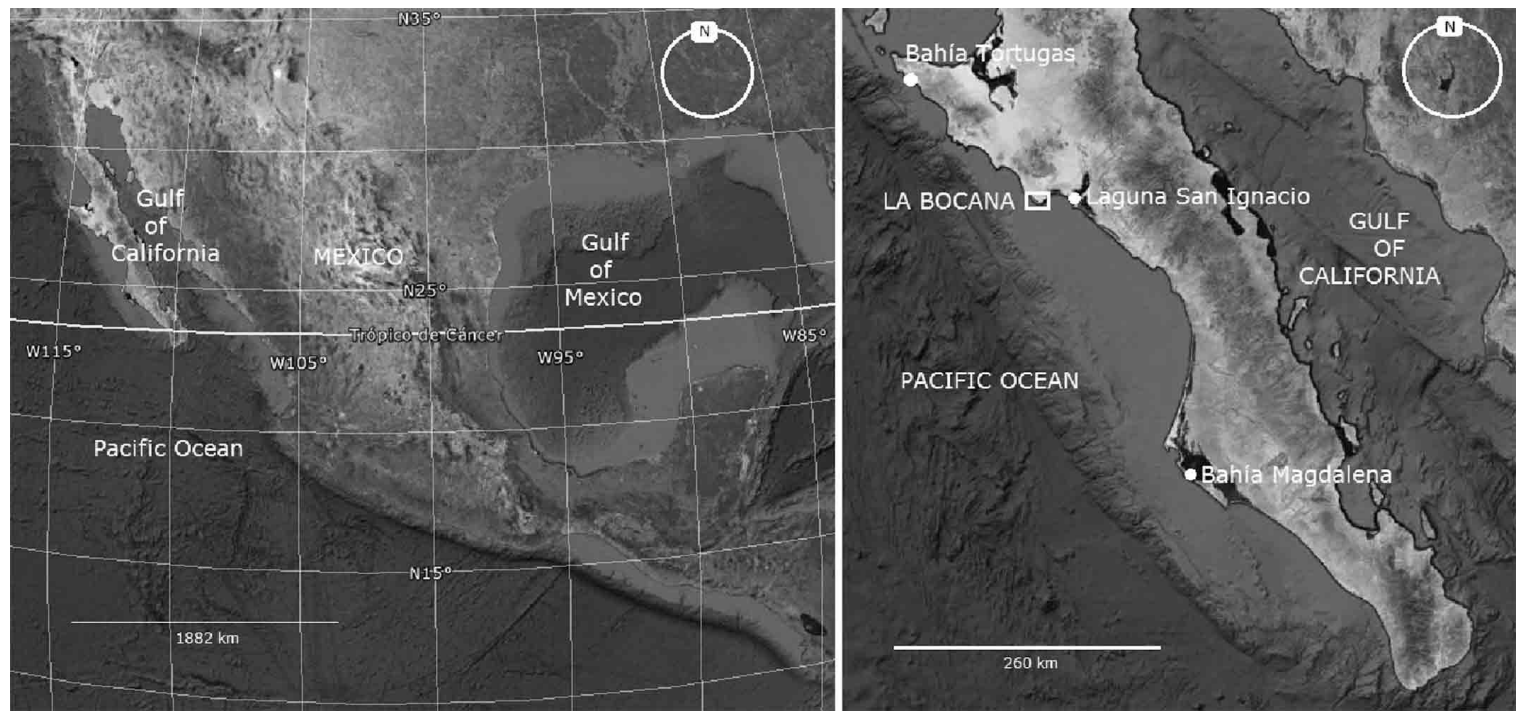

Figure 1. Location of the abalone site La Bocana in the western coast of the Baja California Peninsula, where specimens of Haliotis fulgens and H. corrugata were collected / Localización del sitio abulonero La Bocana en la costa oeste de la Península de Baja California, donde se recolectaron especímenes de Haliotis fulgens and $\mathrm{H}$. corrugata 
Table 1. Sampling dates, number of specimens, and average size of examined adult Haliotis fulgens (Hf) and $\mathrm{H}$. corrugata $(\mathrm{Hc})$ from La Bocana, BCS, M exico. SL= number of slides for identifying diatoms in their gut contents; $\mathrm{ND}=$ no data; WS= sick specimens; $\mathrm{H}=$ healthy specimens; $\mathbf{N}=$ specimens included in the compound sample / Fecha de muestreo, número de especímenes, talla promedio de los adultos examinados de Haliotis fulgens $(\mathrm{Hf})$ y $\mathrm{H}$. corrugata $(\mathrm{Hc})$ de La Bocana, BCS, México. SL= número de laminillas utilizadas para la identificación de las diatomeas en los contenidos intestinales; $\mathrm{ND}=\sin$ datos; $W S=$ especímenes enfermos; $\mathrm{H}=$ especímenes sanos; $\mathrm{N}=$ especímenes incluidos en la muestra compuesta

\begin{tabular}{lccccc}
\hline \multirow{2}{*}{ Date (2012) } & Species & N & Health & SL & Size mm \\
\hline \multirow{2}{*}{ March } & Hc & 9 & WS & ND & 144 \\
& Hf & 10 & H & 5 & 125 \\
April & Hc & 10 & H & 5 & 127 \\
& Hf & 1 & WS & 2 & 154 \\
& Hc & 8 & WS & 5 & 143 \\
May & Hf & 10 & H & 5 & 114 \\
& Hc & 10 & H & 5 & 114 \\
\multirow{4}{*}{ June } & Hc & 1 & WS & 2 & 148 \\
July & Hf & 5 & H & 5 & 128 \\
& Hc & 5 & H & 5 & 137 \\
\multirow{4}{*}{ August } & Hf & 10 & H & 5 & 138 \\
& Hc & 10 & H & 5 & 141 \\
September & Hc & 8 & H & 5 & 131 \\
& Hf & 8 & H & 5 & 139 \\
& Hf & 1 & WS & 2 & 136 \\
& Hc & 3 & H & 5 & 148 \\
& Hf & 10 & H & 5 & 141 \\
& Hc & 4 & H & 5 & 139 \\
\end{tabular}

Specimens from the same species collected in a same date represented a single compound sample, i.e., one of $H$. fulgens and one of $H$. corrugata for each sampling date. To identify diatoms 5 sub-samples or repetitions were separated from the base sample and each one was deposited in a test tube. Then the organic matter from the samples was oxidized using a mixture of nitric acid and commercial alcohol at an initial proportion of 1:3:5 (Siqueiros-Beltrones \& Voltolina 2000) which varied according to the amount of organic matter in each sample. After oxidation the samples were rinsed repeatedly with purified water until reaching a $\mathrm{pH} \geq 6$. From each subsample 2 double permanent slides were mounted using the synthetic resin Pleurax $(\mathrm{IR}=1.7)$.

\section{STRUCTURE OF DiATOM ASSEMblages}

Diatoms were identified at $1000 \times$ under a microscope with phase contrast and planapochromatic optics, using the references in Siqueiros-Beltrones \& Argumedo-Hernández (2015). To estimate the relative abundances (RA) of the diatom taxa 300 valves were counted $(n)$ in a slide representing a sample. Based on said RA species were classified as: abundant (> 25 valves), very common (6$25)$, common (3-5) and rare (1-2), and community parameters were estimated for the diatom assemblages, such as diversity using Shannon's H', Pielou's J' and Simpson's $1-\lambda$ for each sample. Also, similarity between the samples was measured with Jaccard's index which considers only presence-absence of species, and with the Bray-Curtis index which considers both presence-absence of taxa and their RA (Brower et al. 1984).

\section{Results}

The values of the hepato-gonadic index in both abalone species showed the same pattern, a pronounced peak in August-September which depicts both populations reproductive season, followed by a steep decrease in October which reflects spawning events (Fig. 2A). Values are lower for $H$. fulgens than for $H$. corrugata, which indicates that the weight of the hepato-gonadic gland is proportionally lower in comparison with the organisms overall weight. Much lower values were measured for specimens with WS indicating a diminished development of the hepato-gonadic gland as a symptom of the disease. Albeit a similar pattern as in healthy specimens was apparent.

In relation to the condition index, Figure $2 \mathrm{~B}$ shows that for H. fulgens specimens condition remains stable throughout the year with slight variations in April, August and November (2012), and February 2013. The $H$. corrugata values are lower, which indicate that the weight of the individuals without the shell is much lower than its overall weight; this is because $H$. corrugata has a thicker shell that exhibits more fouling than the $H$. fulgens specimens. A pronounced peak in is also observed in May-September 2012 for H. corrugata, which indicates that the specimens were gaining weight, whilst a small decrease in the index value occurred in November. Sick specimens however, showed much lower values compared to those of healthy $H$. fulgens and $H$. corrugata specimens. This makes evident the WS symptoms inasmuch there is a loss of weight and a decrease in weight and size of the callus. However, the specimens collected in April showed higher values than those from previous dates, coinciding with that observed in healthy specimens. 
A

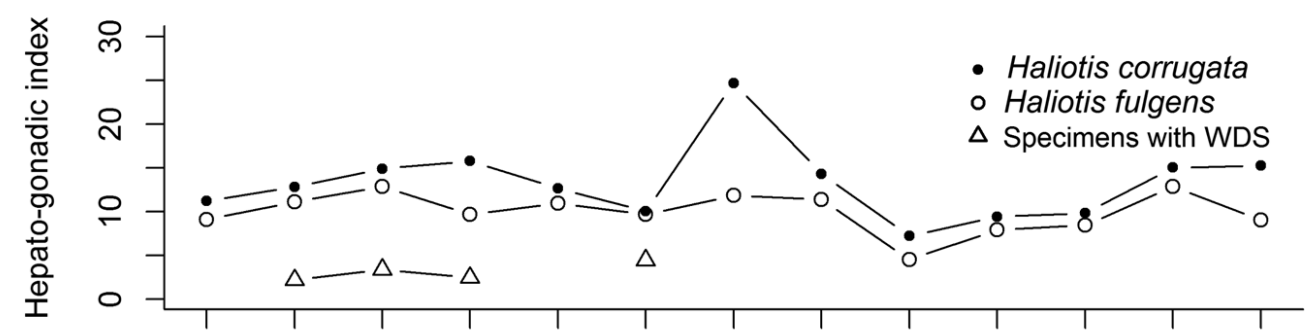

B

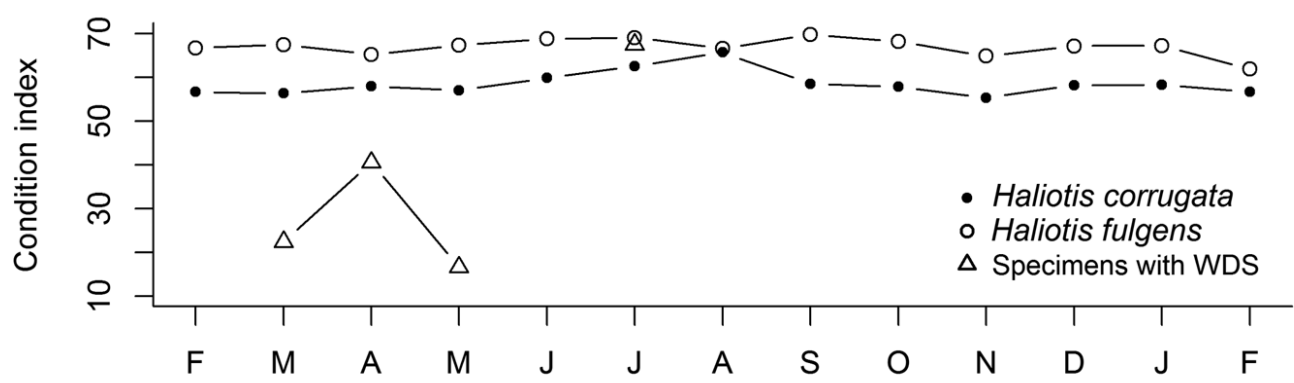

Figure 2. A) The hepato-gonadic index values in both abalone species show the same pattern: a pronounced peak in August-September, and a steep decrease in October. Values are lower for $\mathbf{H}$. fulgens. Condition index values (B) show that in $\mathrm{H}$. fulgens the condition of the organisms remains stable throughout the year with slight lows in April, August and November 2012 and February 2013. Apparently, values were lower for H. corrugata / A) Índice hepatogonadal para ambas especies presentan la misma tendencia: pico pronunciado en agosto-septiembre y marcada disminución en octubre; los valores son más bajos en $\mathrm{H}$. fulgens. El índice de condición (B) muestra que en $\mathrm{H}$. fulgens la condición de los organismos permanece estable a lo largo del año con ligeras disminuciones en abril, agosto y noviembre 2012, y febrero 2013. Aparentemente, en H. corrugata los valores son menores

\section{Diatom DiET ANALYSIS}

Gut content analysis of both species of abalone yielded 149 diatom taxa (species and varieties), mainly epiphytic forms (Siqueiros-Beltrones \& Argumedo-Hernández 2015). The best represented genera were Cocconeis with 17 species, Navicula (15), Amphora (15) and Nitzschia (11) that sum up around $45 \%$ of the floristic inventory. Gut content samples of healthy specimens of $H$. corrugata from August and September did not contain sufficient diatom valves for the quantitative analysis, nor did the April $H$. fulgens specimens with WS. Other samples that yielded quantifiable preparations had low number of diatoms albeit this was observed both for healthy and sick specimens. Absence of diatoms in the guts was observed both in healthy and sick abalone. In the latter, this occurred in specimens from April, which showed peaks in the condition and hepato-gonadic indices (Fig. 2). Diatom species richness (S) in the gut contents appears higher for the Haliotis fulgens suggesting a wider trophic spectrum, whilst in Haliotis corrugata $\mathrm{S}$ is similar to that of the sick specimens, most of which are of the same species.

\section{Structure of The diatom assemblages}

In accordance with our hypothesis, the diatom taxocenosis gathered from the gut contents of $H$. fulgens and $H$. corrugata adult specimens was composed by few abundant taxa and many (55) rare and common taxa depicting a typical benthic diatom assemblage. Overall, the main represented taxa were Grammatophora gibberula, Cocconeis scutellum, and Gomphonemopsis pseudexigua, among the 23 species comprising $80 \%(\mathrm{~N}=$ 1800) of the total RA (Table 2).

While high abundances of taxa such as Bacillaria socialis and Striatella unipunctata coincide for the $H$. fulgens and $H$. corrugata samples from April, that of $G$. pseudexigua coincides in the July samples for both abalone species. The abundance of this diatom species and of $C$. scutellum and Tabularia investiens remained constant throughout the observed dates. In contrast, Rhoicosphenia genuflexa showed an abundance peak in the $H$. corrugata sample from May (Table 3). But in general, the RA of the diatom taxa in every sample (date) were characterized by few abundant taxa and many rare or uncommon species. 
Table 2. Diatom taxa (24) representing $80.5 \%$ of the overall relative abundances (RA) in the gut contents of Haliotis fulgens and $H$. corrugata from La Bocana, BCS, Mexico / Taxones de diatomeas (24) que representaron el $80,5 \%$ del total de la abundancia relativa (RA) en los contenidos intestinales de Haliotis fulgens y H. corrugata de La Bocana, BCS, México

\begin{tabular}{lc}
\hline \multicolumn{1}{c}{ Diatom taxa } & $\mathrm{RA}$ \\
\hline Gomphonemopsis pseudexigua & 13.50 \\
Grammatophora gibberula & 13.33 \\
Cocconeis scutellum & 8.51 \\
Tabularia investiens & 4.30 \\
Rhoicosphenia genuflexa & 4.09 \\
Bacillaria socialis & 3.92 \\
Grammatophora oceanica & 3.86 \\
Navicula parva & 3.30 \\
Striatella unipunctata & 3.11 \\
Ehrenbergia granulosa & 2.67 \\
Nitzschia constricta & 2.32 \\
Navicula cincta & 2.05 \\
Nitzschia frustulum v. perminuta & 1.88 \\
Halamphora coffeaeformis & 1.76 \\
Amphora pusio v. parvulus & 1.67 \\
Gomphoseptatum aestuari & 1.65 \\
Navicula directa & 1.62 \\
Cocconeis diminuta & 1.53 \\
Cocconeis speciosa & 1.16 \\
Amphora pediculus & 1.14 \\
Cocconeis dirupta & 1.11 \\
Podosira stelliger & 1.09 \\
Grammatophora marina & 0.97 \\
Cumulative relative abundance & 80.50 \\
\hline & \\
\hline
\end{tabular}

Table 3. Diatom species (31) representing $>80 \%$ of the relative abundances in gut contents of Haliotis fulgens and $\mathrm{H}$. corrugata, for healthy and sick (WS) from La Bocana, BCS, Mexico / Especies de diatomeas (31) que representaron $>80 \%$ de la abundancia relativa en contenidos intestinales de Haliotis fulgens y $\mathrm{H}$. corrugata sanos y enfermos (WS) de La Bocana, BCS, México

\begin{tabular}{|c|c|c|c|}
\hline Diatom taxa & Hf & $\mathrm{Hc}$ & WS \\
\hline Grammatophora gibberula & 18.17 & 13.06 & \\
\hline Cocconeis scutellum & 12.29 & 6.27 & 2.42 \\
\hline Gomphonemopsis pseudexigua & 12.18 & 11.74 & 19.59 \\
\hline Bacillaria socialis & 5.49 & 3.62 & \\
\hline Tabularia investiens & 3.84 & 4.08 & 5.81 \\
\hline Grammatophora oceanica & 3.80 & 5.58 & \\
\hline Navicula cincta & 3.38 & & \\
\hline Striatella unipunctata & 3.03 & 5.01 & \\
\hline Nitzschia frustulum v. perminuta & 2.54 & & 2.06 \\
\hline Nitzschia constricta & 2.32 & 2.53 & 1.97 \\
\hline Navicula directa & 2.25 & 1.04 & \\
\hline Amphora pusio v. parvulus & 2.22 & 1.55 & \\
\hline Cocconeis diminuta & 1.83 & 1.04 & 1.52 \\
\hline Podosira stelliger & 1.37 & 1.32 & \\
\hline Grammatophora hamulifera & 1.34 & & \\
\hline Cocconeis dirupta & 1.30 & & \\
\hline Catacombas gallionii & 1.19 & & \\
\hline Grammatophora marina & 0.95 & 1.38 & \\
\hline Cocconeis placentula & 0.88 & & \\
\hline Cocconeis speciosa & 0.88 & & 3.22 \\
\hline Rhoicosphenia genuflexa & & 10.88 & 3.58 \\
\hline Gomphoseptatum aestuari & & 4.32 & \\
\hline Melosira nummuloides. & & 2.13 & \\
\hline Amphora bigibba & & 1.44 & \\
\hline Navicula cf. agnita & & 1.44 & \\
\hline Halamphora coffeaeformis & & 1.32 & 5.19 \\
\hline Nitzschia distans & & 1.27 & \\
\hline Nitzschia dissipata v. genuina & & 1.04 & \\
\hline Navicula parva & & & 16.82 \\
\hline Ehrenbergia granulosa & & & 12.70 \\
\hline Amphora pediculus & & & 5.81 \\
\hline Relative abundances & 2840 & 1738 & 1118 \\
\hline Cumulative relative abundances & 81.27 & 82.05 & 80.68 \\
\hline
\end{tabular}


The estimated values used to describe the assemblage structure (Table 4) show high species diversity of diatoms where the major components are high species richness and low dominance. In a single case (Hc June) the equitability contributed the most to the high diversity, having the overall high value of $\mathbf{J}^{\prime}$. And, as with the RA the measured values throughout the sampling period (Fig. 3) agree with our hypothesis, inasmuch the diversity values and its components fall within the ranges $\left(1>\mathrm{H}^{\prime}<\right.$ 5) that characterize typical benthic diatom assemblages (Siqueiros-Beltrones 2005). Thus, these are considered to be accurately represented in the analyzed gut contents, while indicating that the available diatom flora in the

Table 4. Estimated values of the indices that describe the structure of diatom assemblages represented in the gut contents of Haliotis fulgens (Hf) and $\mathrm{H}$. corrugata (Hc) collected at La Bocana, BCS. S= Species richness; $\mathbf{N}=$ Sample size; J'= Pielou's equitability; $\mathbf{H}^{\prime}=$ Shannon's diversity; $\lambda=$ Simpson's dominance; $1-\lambda=$ Simpson's diversity; $\mathrm{W}=$ specimens with $\mathrm{WS}$; $\mathrm{ND}=$ no diatoms present; $\mathrm{NP}=$ not processed for diatoms / Valores calculados de los índices que describen la estructura de asociaciones de diatomeas representadas en contenidos intestinales de Haliotis fulgens ( $\mathrm{Hf}$ ) y $\mathrm{H}$. corrugata $(\mathrm{Hc})$ de La Bocana, BCS. S= Riqueza de especies; $\mathrm{N}=$ Tamaño de muestra; $J^{\prime}=$ Equidad de Pielou; $H^{\prime}=$ Diversidad de Shannon; $\lambda=$ Dominancia de Simpson; $1-\lambda=$ Diversidad de Simpson; $W=$ especímenes con síndrome de deshidratación; $N D=\operatorname{Sin}$ diatomeas; $\mathrm{NP}=$ No procesados para diatomeas

\begin{tabular}{lcccccc}
\hline \multicolumn{1}{c}{ Sample } & $\mathrm{S}$ & $\mathrm{N}$ & $\mathrm{J}^{\prime}$ & $\mathrm{H}^{\prime}$ & $\lambda$ & $1-\lambda$ \\
\hline Hc March NP & & & & & & \\
Hf March & 28 & 302 & 0.647 & 3.11 & 0.193 & 0.807 \\
Hc March & 34 & 322 & 0.769 & 3.92 & 0.113 & 0.887 \\
Hf April & 45 & 404 & 0.642 & 3.53 & 0.169 & 0.830 \\
Hf April W ND & & & & & & \\
Hc April & 35 & 331 & 0.781 & 4.00 & 0.091 & 0.909 \\
Hc April W & 39 & 333 & 0.576 & 3.05 & 0.282 & 0.718 \\
Hc May W & 30 & 429 & 0.716 & 3.52 & 0.153 & 0.847 \\
Hf May & 61 & 397 & 0.773 & 4.58 & 0.084 & 0.916 \\
Hc May & 24 & 370 & 0.550 & 2.52 & 0.304 & 0.696 \\
Hf June & 34 & 374 & 0.752 & 3.83 & 0.134 & 0.866 \\
Hc June & 39 & 390 & 0.806 & 4.26 & 0.076 & 0.924 \\
Hf July & 41 & 304 & 0.703 & 3.77 & 0.150 & 0.850 \\
Hc July & 37 & 325 & 0.691 & 3.61 & 0.169 & 0.831 \\
Hf July W & 34 & 356 & 0.556 & 2.83 & 0.330 & 0.671 \\
Hf August & 23 & 347 & 0.549 & 2.48 & 0.299 & 0.701 \\
Hc August ND & & & & & & \\
Hf September & 40 & 315 & 0.759 & 4.04 & 0.092 & 0.908 \\
Hc September ND & & & & & & \\
\hline
\end{tabular}

abalone environment is highly diverse. Also, in agreement with our hypothesis no difference is apparent in the structure of diatom assemblages represented in the gut contents of $H$. fulgens as compared to $H$. corrugata, nor in the gut contents of specimens with WS.

\section{Similarity BetWeEn SAMPLeS}

Similarity measurements between samples based on presence/absence of taxa suggests that both abalone species feed on the same diatom species available in their shared habitat, inasmuch the highest similarity observed was between samples of either species from the same date (Fig. 4). This comprises also the gut content samples from specimens with WS, and although the April sample of sick $H$. corrugata showed the minimum similarity, the other 2 samples fall in indiscriminately. Likewise, this agrees with the outcome of the Bray-Curtis index (Fig. 5), thus showing that the more abundant diatom taxa are distributed in similar proportions among the gut content samples from the same dates. The high relative abundances of certain diatom taxa from the specimens with WS (Table 4) do not suggest any other type of relation.

\section{Discussion}

No apparent coincidences could be appreciated between parameter measurements of the diatom samples and the condition or hepato-gonadic indices of either abalone species that could suggest changes in feeding habits throughout the sampling period. However, such constancy strongly suggests that adult abalone feed nonselectively on the epiphytic diatoms available in situ as juveniles do (Siqueiros-Beltrones et al. 2004, 2005), and supports the representativeness of the diatom based diet for adults of both abalone species, which applies to both healthy and sick specimens.

There are few studies that relate reproductive aspects of haliotids with their diet; most refer to the macroalgaebased diet (Muñoz \& Ambler 2012, Mardones et al. 2013). Until now, most observations on the role of diatoms in the diet of abalone have referred to juveniles or postlarvae. This precludes any comparative analysis inasmuch no studies on the diatom based diet of adult abalone were available until now. Also, much limitation has existed hitherto with the gathering of enough abalone specimens from their natural environment for studying. Thus, although our results are strongly exploratory, they are well supported by the numerous specimens used in our observations. 

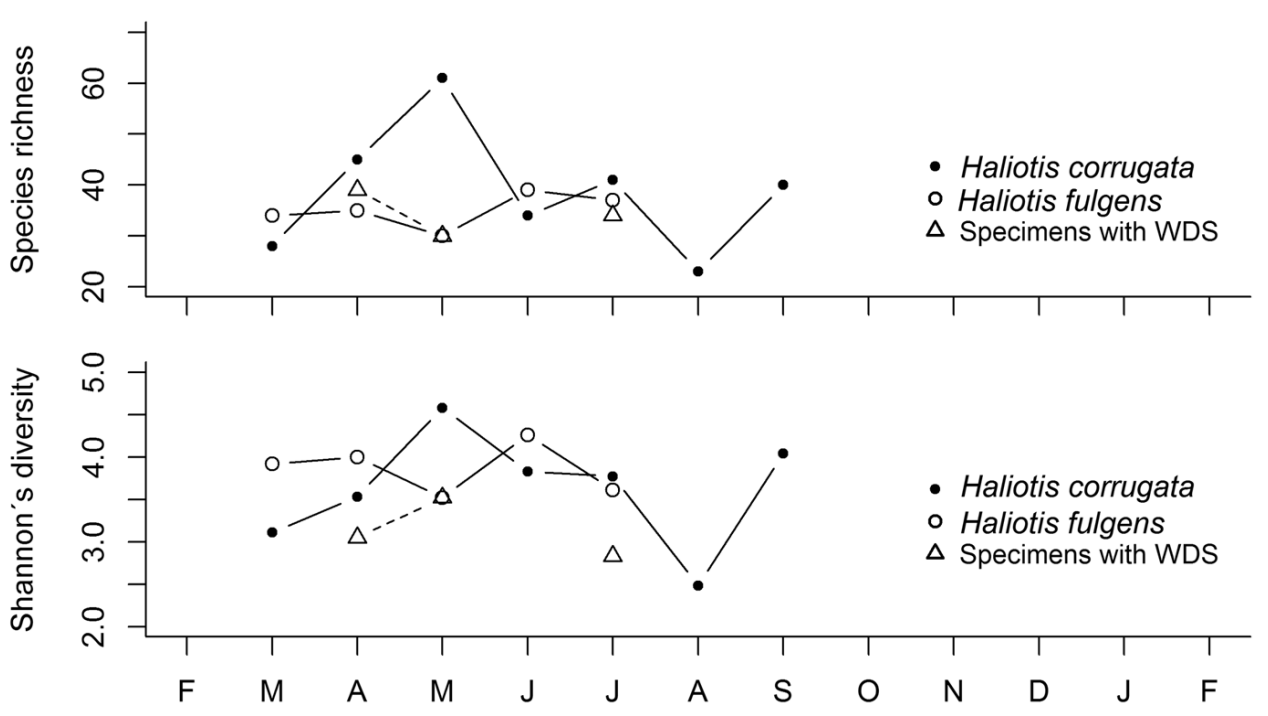

Figure 3. Species richness and species diversity $\left(\mathrm{H}^{\prime}\right)$ values for the diatom assemblages represented in the gut contents of adult abalone collected at La Bocana, BCS, Mexico at different dates / Valores de riqueza y diversidad ( $\left.\mathrm{H}^{\prime}\right)$ de especies para las asociaciones de diatomeas representadas en contenidos intestinales de abulones adultos recolectados en La Bocana, BCS, México en fechas distintas

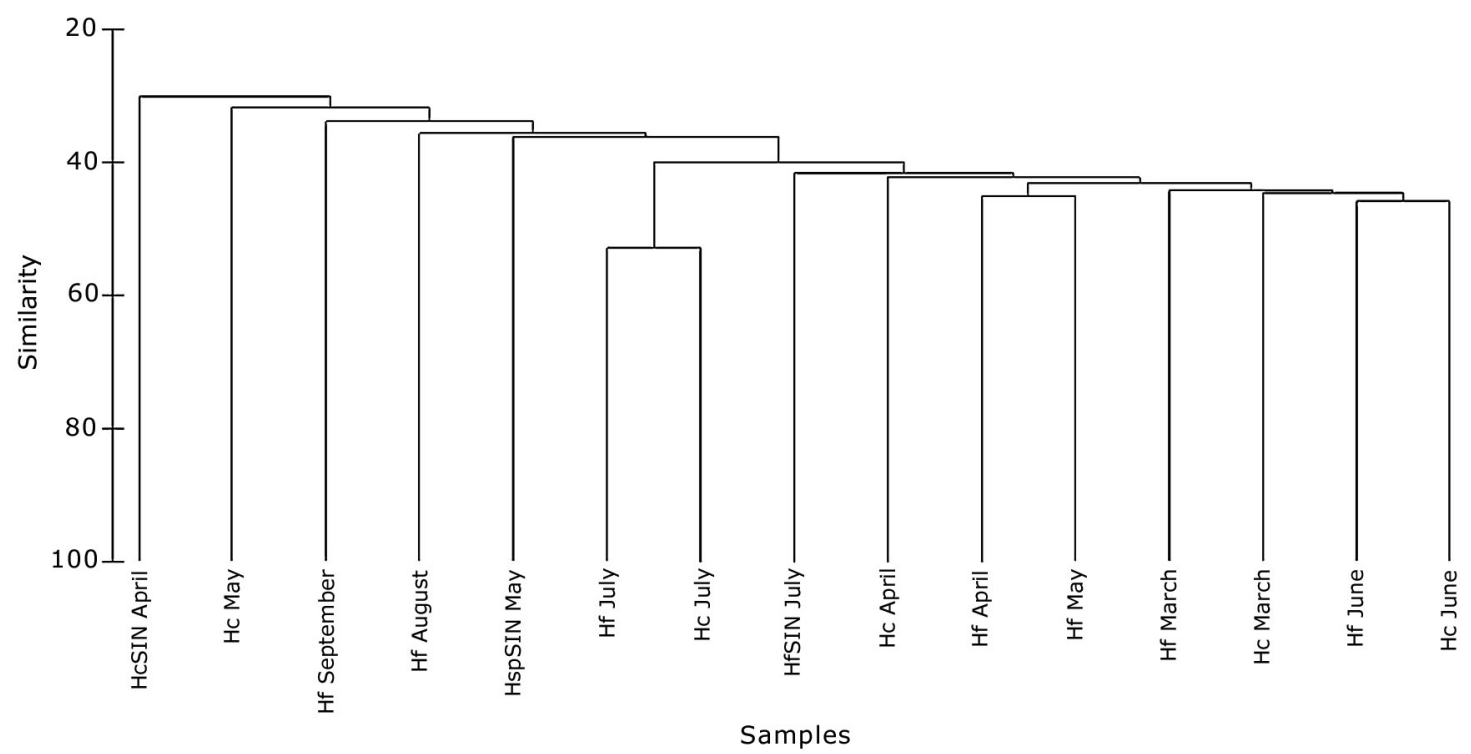

Figure 4. Similarity between diatom samples in the gut contents of Haliotis fulgens and H. corrugata collected at La Bocana, BCS, based on presence/absence of taxa (Jaccard's index). SIN= specimens with WS / Similitud entre muestras de contenidos intestinales de Haliotis fulgens y H. corrugata recolectados en La Bocana, BCS, de acuerdo a presencia y ausencia de taxones (índice de Jaccard). SIN= especímenes enfermos 


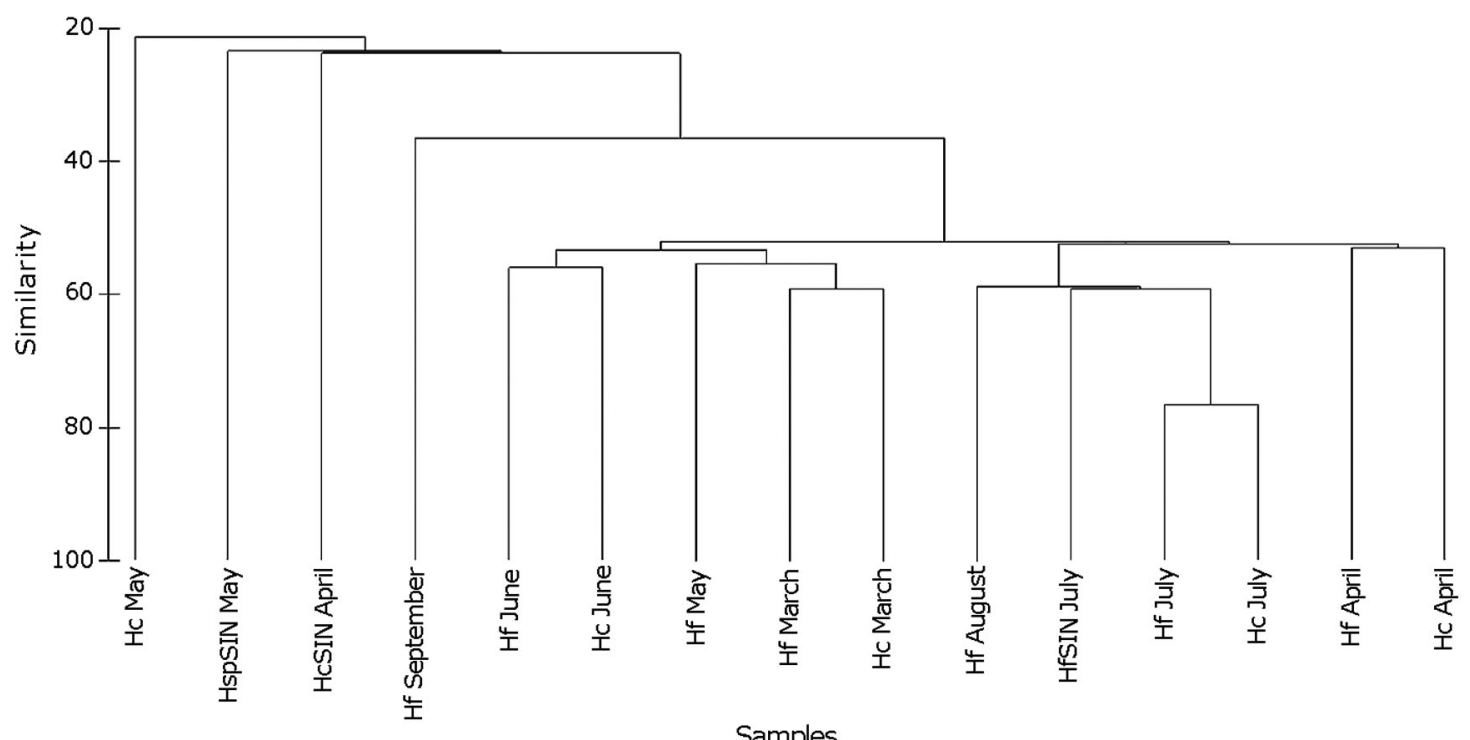

Figure 5. Similarity between diatom samples in the gut contents of Haliotis fulgens and H. corrugata collected at La Bocana, BCS, based on the relative abundances of shared taxa (Bray-Curtis index). SIN= specimens with WS / Similitud entre muestras de diatomeas de contenidos intestinales de Haliotis fulgens y $\mathrm{H}$. corrugata recolectados en La Bocana, BCS, de acuerdo con abundancias relativas de los taxones compartidos (índice de Bray-Curtis). SIN= especímenes enfermos

The diatom species richness measured in gut contents of the 2 abalone species from this study (149) compared to other studies dealing with juveniles Haliotis spp. (150) is very similar (Siqueiros-Beltrones et al. 2004, 2005). Representative taxa from this list are provided in an iconographic catalog supporting this study (SiqueirosBeltrones \& Argumedo-Hernández 2015). However, the assumption that the natural diatom assemblages are represented accurately in the samples from gut contents of abalone may be questionable, inasmuch the total number of diatom taxa found in gut contents of the adult $H$. fulgens and $H$. corrugata examined represent only half of the diatom taxa recorded in situ in the same region (Siqueiros-Beltrones et al. 2004). Differences in feeding habits could explain this, as well as the heterogeneity of the habitat as with other grazing molluses such as chitons (Siqueiros Beltrones \& Argumedo-Hernández 2012). On the other hand, 24 out of the 37 diatom taxa previously recorded as the most abundant in gut contents of young abalone from Bahía Tortugas and Bahía Asunción, north of La Bocana (Siqueiros-Beltrones et al. 2005) were listed in our study, which suggests that both adults and juveniles feed mostly on the most common macroalgae harboring these epiphytic diatom species.
The main diatom taxa in this study such as Cocconeis scutellum and Gomphonemopsis pseudexigua have been reported as such in previous studies, but Grammatophora gibberula for example, stands out as a new important taxon in the diet of abalone. Whilst, taxa such as Cocconeis costata var. pacifica and $C$. speciosa recorded as abundant in gut contents of abalone juveniles (Siqueiros-Beltrones et al. 2005) were absent or very scarce. Higher frequency sampling as well as longer term (year to year) representations are required to determine if diatom assemblage variations are responsible for the observed discrepancies.

The high values of diatom species diversity and the similarity between samples of gut contents from both abalone species and from healthy or sick specimens represent typical benthic diatom assemblages (SiqueirosBeltrones 2005) and support our hypothesis that no difference would be found in the structure of the diatom assemblages represented in the gut contents of $H$. fulgens as compared to $H$. corrugata. This suggests that the diatom assemblages in the shared habitat are the same and that their feeding habits are very similar. Also, it is most likely that adult abalone feed non-selectively on the available diatom assemblages, as it has been observed 
with juveniles, although most diatoms are epiphytic forms suggesting that abalone go for the macroalgae. It is also probable that the higher frequency of certain diatom taxa in the samples varies seasonally and in shorter periods depending on the growth of the host macroalgae. Unlike our present study which is mostly exploratory and, thus, not designed to apply rigorous statistical techniques Higher frequency observations based on simultaneous sampling are needed to test the hypothesis that no differences exist in the diatom based diet of abalone adults and juveniles of either species, supported on a priori selected statistical tests.

In relation to the health of the abalone specimens, even though our second hypothesis on the diet of abalone with WS is not refuted, i.e., that the diatom assemblages in sick specimens would be similar to those of healthy specimens, our reasoning dealt with the feeding anomalies leading to their malnutrition and eventual death. The 'normal' contents in their guts, as shown by the presence of representative diatom samples, along with the lower values in the condition index suggest more of a digestive inability than a feeding inability. Observation of fresh samples from fecal material may serve to clear this out in a later study.

\section{ACKNOWLEDGMENTS}

This study was supported by the Secretaría de Investigación y Posgrado, Instituto Politénico Nacional, through projects: SIP-20130868; SIP 20121218; SIP 20130751. Abalone specimens were provided by Cooperativa Progreso at La Bocana BCS, through project 'Diagnóstico sobre la disminución de las poblaciones de abulón en la costa occidental de la Península de Baja California y estrategias para atenuar los impactos negativos' of the Centro Regional de Investigaciones Pesqueras at La Paz, financed by SAGARPA-CONACYT. We acknowledge the reviews by two anonymous referees. The first and fourth authors are COFAA and EDI fellows.

\section{LITERATURE CITED}

Argumedo-Hernández U \& DA Siqueiros-Beltrones. 2010. Non selective in situ grazing of diatoms by juvenile green abalone (Haliotis fulgens Philippi, 1945). Hidrobiológica 20(1): 13-19.

Brower JE, JH Zar \& KN von Ende. 1984. Field and laboratory methods for general ecology, 273 pp. McGraw-Hill, Boston.

García-Esquivel Z, J Cáceres-Martínez \& S MontesMagallón. 2011. Oxytetracycline water bath treatment of juvenile blue abalone Haliotis fulgens (Philippi 1845) affected by the withering syndrome Ciencias Marinas 37(2): 191-200.
Guzmán del Próo SA, E Serviere-Zaragoza \& D Siqueiros Beltrones. 2003. Natural diets in young abalone, Haliotis fulgens and H.corrugata (Mollusca: Gastropoda) in Bahía Tortugas, B.C.S., México. Pacific Science 57(3): 319-324.

Mardones A, A Augsburger, R Vega \& P De los RiosEscalante. 2013. Growth rates of Haliotis rufescens and Haliotis discus hannai in tank culture systems in southern Chile (41.5 ${ }^{\circ}$ ). Latin American Journal of Aquatic Research 41(5): 959-967.

Muñoz P, R Ambler \& C Bulboa. 2012. Settlement, survival, and post-larval growth of red abalone, Haliotis rufescens, on polycarbonate plates treated with germlings of Ulva sp. Journal of the World Aquaculture Society 43(6): 890-895.

Mazariegos-Villarreal A, M Casas-Valdez, DA SiqueirosBeltrones, A Piñon-Gimate \& E Serviere-Zaragoza. 2012. Changes in the natural diet of green abalone (Haliotis fulgens Philippi 1845), during the 1997-1998 ENSO, in Baja California Sur, Mexico. Journal of Shellfish Research 31(3): 795-800.

Salas-Garza A \& R Searcy-Bernal. 1992. Desarrollo y estado actual del cultivo de abulón en México. In: Shepherd S, MJ Tegner \& SA Guzmán del Próo (eds). Abalone of the world: Biology, fisheries and culture, pp. 538-546. Fishing News Books, Oxford.

Serviere-Zaragoza E, D Gómez-López \& G Ponce-Díaz. 1998. The natural diet of green abalone (Haliotis fulgens Philippi) In the Southern part of its range, Baja California Sur, Mexico, assessed by an analysis of gut contents. Journal of Shellfish Research 17(3): 777-782.

Siqueiros-Beltrones DA. 2002. Diatomeas bentónicas de la Península de Baja California; diversidad y potencial ecológico, 102 pp. Oceánides/CICIMAR-IPN/UABCS, La Paz.

Siqueiros-Beltrones D. 2005. Una paradoja sobre uniformidad vs. orden y estabilidad en la medida de la diversidad de especies según la teoría de la información. Ludus Vitalis 13(24): $1-10$

Siqueiros-Beltrones DA \& U Argumedo-Hernández. 2012. Diversidad de diatomeas en la dieta in situ de Chiton virgulatus Sowerby, 1840 (Mollusca: Polyplacophora) de Baja California Sur. Hidrobiológica 22(3): 267-281.

Siqueiros-Beltrones DA \& U Argumedo-Hernández. 2015. Diatomeas epifitas consumidas por adultos de abulón (Haliotis spp.) en BCS, México. Revista Mexicana de Biodiversidad 86(1): 111-122.

Siqueiros-Beltrones DA \& D Voltolina. 2000. Grazing selectivity of red abalone Haliotis rufescens poslarvae on benthic diatom films under culture conditions. Journal of the World Aquaculture Society 31(2): 239-246.

Siqueiros-Beltrones DA, G Valenzuela-Romero, O Hernández-Almeida, U Argumedo-Hernández \& FO López-Fuerte. 2004. Catálogo iconográfico de diatomeas de hábitat rocosos y su incidencia en la dieta de abulones (Haliotis spp.) jóvenes de Baja California Sur, México. (México) CICIMAR Oceánides 19(2): 1-79. 
Siqueiros-Beltrones DA, E Serviere-Zaragoza \& S Guzmán del Próo. 2005. Main diatom taxa in the natural diet of juvenile Haliotis fulgens and H. corrugata (Mollusca: Gastropoda) from Bahía Tortugas and Bahía Asunción, B.C.S., México. Pacific Science 59(4): 581-592.

Villalejo-Fuerte M \& BP Ceballos-Vázquez. 1996. Variación de los índices de condición general, gonádico y de rendimiento muscular en Argopecten circularis (Bivalvia: Pectinidae). Revista de Biología Tropical 44: 591-594.
Webber HH \& AC Giese. 1968. Reproductive cycle and gametogenesis in the black abalone Haliotis cracherodii (Gastropoda: Prosobranchiata). Marine Biology 4: 152159.

Zetina ZA, D Aldana, T Brule \& E Baqueiro. 2000. Ciclo reproductor e índices de condición usados en Melongena corona (Mollusca: Gastropoda). Revista de Biología Tropical 48(1): 77-86.

Received 28 April 2014 and accepted 23 March 2015

Editor: Claudia Bustos D. 